\title{
Democratic Transition and Democratization in Francophone Africa
}

\author{
By Emeka Nwokedi
}

\section{Introduction}

The upsurge in mass protests in favour of democratization in sub-Saharan Africa beginning from 1989 has served to bring democracy back in as a central focus in the analysis of Africa's political process thus vindication, albeit unwittingly, Richard Sklar's plea made in 1982 for this concept to be given a chance on the continent.1 To reflect upon democraizavion is to inquire into the premises and promises of democracy within the countries that have embarked upon this political transformation. It seems to us that such an inquiry demands a critical examination of four basic issues: the context within which this quest has arisen, the expectations which underpin it as well as the imponderables confronting it, the mechanisms through which it is being realized and, last but not the least, the import of the whole process for a meaningful development in the states concerned.

Because the democratic demands that have emerged are, in actual fact, manifestations of political upswellings from civil society we propose to situate this analysis within the framework of the interactions between these two conceptual variables. The reason for this choice is straightforward. The political system itself deals with relationships between the state and civil society. While a focus on the state is indispensable, it is often static and gives only a partial view of the complexities of political processes. Thus we share the preoccupation of Victor Azarya and Naomi Chazan when they argue that an exclusive or an excessive focus on the state reveals how this entity acts upon the society without correspondingly paying an adequate attention to how these societies in turn react to or cope with the actions of the former. ${ }^{2}$ Second, there is merit in accepting Jean-François Bayart's contention that "it seems most profitable to explain the continued quest for democracy as a

1 Richard L. Sklor, Democracy in Africa, Af rican Studies Review, vol. 26 (3\&4), 1983, pp. 11-24. Future references will come from the same article published as chapter 12 in R.L. Sklar / C.S. Whitaker, African Politics and Problems in Development, Boulder, Col., 1991.

2 Victor Azarya / Naomi Chazan, Disengagement from the State in Africa: Reflections on the Experience from Ghana and Guinea, Comparaive Studies in History and Society, vol. 29 (1) 1987, pp. 107-108; Victor Azarya, Reordering State-Society Relations: Incorporation and Disengagement, in: D. Rothchild / N. Chazan (eds.), The Precarious Balance: State and Society in Africa, Boulder, Col., 1988, p. 5; N. Chazan, Patems of State-Society Incorporation and Disengagement in Africa, in: Ibid., p. 122. 
commentary upon the relationship between the state and civil society (hence) it is in light of this dichotomy (between the state and civil society) that it is necessary to study democracy, authoritarianism and even totalitarianism in Africa". ${ }^{3}$ The point is that political regimes do not operate in vacuo, they are largely a function of the balance of forces between the state and civil society at any given point in time. What then is civil society and how does it help in apprehending the democratization process?

\section{State-Civil Society Relations}

The question as to whether or not African states are really one given the low capacity of many of them to exercise effective jurisdiction over their national territories has often been posed. 4 All too frequently, the polemics centre on the validation of the sociological criteria of statehood. Robert Jackson and Carl Rosberg have pointed out that Max Weber's sociological definition of the state as the latter so acknowledged, was based on 'means' and not 'ends' of statehood. Such a definition framed on means of force "emphasizes the empirical rather than the juridical, the de facto rather than the de jure attributes of statehood".5 In order to circumvent the controversies on the true nature of the African state, we follow Jackson and Rosberg in asserting the persistence and, a fortiori, the existence of this state on the basis of the juridical attributes of statehood. 6

The concept of the state is complemented by that of civil society which is conceived as the space between the state and the family where private interests thrive. Roberg Fatton Jr defines civil society as the "private sphere of material, cultural, and political activities resisting the incursions of the state". 7 To R. Fossaett, it is "society in relation with the state ... in so far as it is in confrontation with the state". 8 The foregoing definitions underscore the position of civil society as a counterpoise to the state but, Michael Bratton, who takes an exception to this confrontational posture, has pointed out that in Hegel's formulation of this concept and in that of Gramsci, civil society was never conceived as being in confrontation with the state. According to Bratton, these theorists conceived it as "either a step on the way to state formation (Hegel) or a handmaiden in the state's project of domination

3 J.-F. Bayart, Civil Society in Africa, in: P. Chabal (ed.), Political Domination in Africa: Reflections on the Limits of Power, Cambridge, 1986, pp. 111 \& 113.

4 See for example, B. Badie / P. Birnbawn, Sociologie de l'Etat, Paris, 1979, pp. 178, 181.

5 RH. Jackson / C.G. Rosberg. Why Africa's Weak States Persist: The Empirical and the Juridical in Statehood, World Politics, vol. 35 (1), October 1982, p. 2.

6 Ibid., p. 13.

7 R. Falton Jr, Democracy and Civil Society in Africa, Mediterranean Quarterly, vol. 2 (4), Fall 1991, p. 84.

8 R. Fossaert, La Société. Les Etats, tơne 5, Paris, 1981, 146-147. 
(Gramsci)".9 Given this, Alfred Stepan's 'neutral' definition is preferred by Bratton: "an arena where manifold social movements ... and civic organizations from all classes ... attempt to constitute themselves in an ensemble of arrangements so that they can express themselves and advance their interests".10 Bratton's principal objection to the confrontational posture between the state and civil society is anchored on the fact that fledgling civic associations in Africa are being expected to shoulder the "onerous burden of opposition in a context where state elites are prone to equate opposition with disloyalty and treason".11 But civic associations will not always remain fledgling nor will the context of state-society interactions remain non-democratic or hostile. Moreover, nothing suggests from Stepan's definition that the advancement of interests by civil society will always exclude all shades of confrontation.

Whatever is the case, contemporary usage conceives of civil society as being in a positive conflictual relationship with the state. To be sure, there is much overlap between the two entities thus, Fossaert will identify seven types of civil society and will posit that each civil society has its own state and each state, its own civil society even if the latter is reduced to the thin spread of families in village communities. 12 The value of a conceptual distinction between the two entities then is to enable the identification of voluntary organizations, political formations, labour unions and professional associations as the constitutive elements of civil society because they are not part of the formal structures of govemment. While this distinction does not dissipate entirely the controversies which this concept generates in the literature, it does serve a heuristic purpose contrary to the skepticism which both Mahmood Mamdani and Archie Mafeje, for example, express about its suitability for grasping contemporary political reality in sub-Saharan Africa.13 Noberto Bobbio and Jean Leca have credited civil society with legitimating and delegitimating functions vis-a-vis the state. In adopting what amounts to the location of popular sovereignty within civil society, Bobbio identifies the latter as the "place where, especially in periods of institutional crisis, de facto powers are formed that aim at obtaining their own legitimacy even at the expense

9 M. Bratton, Beyond the State: Civil Society and Associational Life in Africa, World Politics, vol. XLI (3), April 1989, p. 417.

10 A. Stepan, Rethinking Military Politics: Brazil and the Southem Cone, Princeton, N.J., 1988, pp. 34 as cited in $M$. Bratton, ibid.

11 Ibid

12 R. Fossaert, La Société. Les Etats, tome 5, p. 224.

13 M. Mamdani, A Glimpse at African Studies made in USA, Southem African Political and Economic Monthly, vol. 4 (1), 1990, p. 31; A. Mafeje, Theory of Democracy and the African Discourse: Breaking Bread with my Fellow Travellers, Paper presented at CODESRIA's Seventh General Assembly at Dakar, February 10-14, 1992 on the theme "Democratization Process in Africa, Problems and Prospects", p. 23. 
of legitimate power; where, in other words, the process of delegitimation and relegitimation take place".14

In the light of the foregoing, there is great merit in a simultaneous focus on state and civil society in order to apprehend the complex factors that underlie the processes of democratization in francophone Africa. The tendency of the state to dominate and to control civil society has been underscored in the literarure. The study by Azarya and Chazan identify members of civil society in Africa as reacting to the state by adopting the strategies of incorporation into or disengagement from this entity according to changing circumstances. 15 If J.-F. Bayart is correct, "the concept of civil society seems best able to explain - by its absence - the continuing existence of African autocracy".16 It becomes interesting then to conceive of the processes of democratization as permitting the projection of civil society in the sub-Saharan French-speaking states thus holding out prospects for the demise of authoritarianism and for the rebirth of democracy. Through democratization is posed the problem of representation - a role for civil society - which Leca considers as enabling all those excluded from the political field from making known their views. 17

Having said this, it is appropriate from the outset to delineate, on the one hand, our parametres of democratization and, on the other hand, to justify our choice of focus. Democratization refers to the process of a shift from non-democratic forms of government to a democratic form of government. This entails the creation and the consolidation of democratic space. It can be conceived of, additionally, as a process involving a progressive intemalization of democratic norms and values by practitioners as well as a continuous institutionalization of its procedures and structures within both the state and civil society of the hitherto non-democracies. Jean Grugel has assered that in Latin America this concept has been about "building systems of political domination based on only formal and hence limited popular participation and some accomodation with the authoritarian order ...".18 This is a restrictive description because it is concemed only with a distinct phase of democratization.

$14 N$. Bobbio, Democracy and Dictatorship, Minneapolis, 1989, p. 26 as cited in R. Fatton Jr, Democracy and Civil Society in Africa, p. 85; J. Leca, La visite à la vieille dame ou la société civile revisitée', paper presented at a Round Table on "Changements Politiques en Afrique du Nord, Transformations Sociales et Régulations des Conflits", IREMAN, Aix-en-Provence, 5-7 October 1989, pp. 5-6. Leca will trace the integral concepion of civil society to the works of Thomas Hobbes, Elements of Law (1640) and particularly De Cive (1649). See also, F. Rangeon, Société civile: Histoire d'un Mot, in: J. Chevalier (ed.). La Société Civile, Paris, 1986, pp. 14-16.

15 V. Azarya / N. Chazan, Disengagement from the State in Africa, p. 108.

16 J.-F. Bayart, Civil Society in Africa, p. 119.

$17 \mathrm{~J}$. Leca, La visite à la vieille dame, p. 18.

18 J. Grugel, Transitions from Authoritarian Rule: Lessons from Latin America, Political Studies, vol. 39 (2), June 1991, p. 363. 
Democratization is a long term process during which multiple processes are at work simultaneously thus permitting a differentiation between its varying phases. It is in this light that Daniel Levine's two-tier delineation of the concept becomes quite apt:

The first (sense) is temporal: democratization as a stage in the creation and maintenance of democracy. Relevant phases may run from initial decay of the old regime and inauguration of a new system, through consolidation to (hoped-for) maturity. The second phase of democratization refers to the creation, nurture, and spread of more egalitarian social relations and norms of leadership and authority. These are rooted in greater social and economic equity, and worked out in associational life, especially through encouragement of participation, the development of new sources and styles of leadership, and generally in the way group life is linked to the big structures of national politics. 19

To conceive of democratization along these lines permits us to argue that democratic transition, defined here narrowly as the outcome of this shift, is a sub-set of democratization and, therefore, one of its vital phases. This is the sense in which Grugel's description of this process in Latin America ought to be taken. If this viewpoint is accepted, we could then distinguish between two basic types of democratic transitions: complete and incomplete or partial democratic transions. It is complete when democratization results in the emergence in power of a new leadership with a new political orientation. The converse is true for a partial democratic transition. This describes a situation where an incumbent military dictator converts to a civilian president - civilianization - under the guise of democratization or when long-serving civilian presidents retain their positions after winning multiparty elections held as part of the democratization process. Partial democratic transition could then be considered as a mere political liberalization or what French Africanists refer to as a decompression of authoritarianism.20

Although democratization is concerned with the creation or the expansion of democratic spaces, there is hardly any consensus among scholars on what democracy itself is. For the purposes of this essay we define it, following Larry Diamond and his colleagues as:

... a system of govemment that meets three essential conditions: meaningful and extensive competision among individuals and organized groups (expecially political parties) for all effective positions of government power, at regular intervals and excluding the use of force; a highly inclusive level of political participation in the

19 DH. Levine, Paradigm Lost: Dependence to Democracy, Review Article, World Politics, vol. XL (3), April 1988, p. 383.

20 See for example, J.-F. Bayart, La Problématique de la démocratie en Afrique noire: 'La Baule, et puis après?', Politique Africaine, No. 43, Ociober 1991,p. 12. 
selection of leaders and policies, at least through regular and fair elections ... and a level of civil and political liberties. 21

Contemporary democratic theories stress multipartyism, the institutionalization of the opposition as well as the respect for this role and the application of political accountability especially through the electoral process.22 While the interpretation of the qualifying attributes of the first two conditions enunciated by Diamond et al is debatable, it is obvious that these underscore the extent to which transparency is considered as a democratic virtue.

This having been said, we precise that the focus of this essay is on sub-Saharan Frenchspeaking states and the reason for this choice is that democratic African states suggesting the existence of a certain level of criss-crossing influences. The nature of their specificity enables us to pose the following questions: What accounts for the high incidence of vehemence between the state and civil society in the quest for democratization in these states? Why is the use of the national conference as a mechanism for democratic transition exclusive to this group of states, some of them that is? Against the backdrop of the overall rationale for democratization, would a comparative analysis of the transition processes in these states reveal a significant shift in their regime types? What do all this portend, in the final analysis, for socio-economic development in the states concemed?

This essay is divided into four sections. In the first we undertake a general reflection on the context within which this democratization has arisen; the second discusses the differing pattems of the democratization process with a view to responding to some of our interrogations and to examining the consequences of this for state-civil society relations in these states. Subsequently, we undertake an appreciation of this democratization as an enabling environment for a meaningful economic development within this group of states. The conclusion will serve as a kind of synthesis and will equally attempt to reflect upon the prospects for democracy in the states under consideration.

\section{The Context of Democratization}

To examine the context in which the demands for democratization have arisen in the subSaharan francophone states implies accounting for the absence of democracy itself and an analysis of the circumstances which have thrown up these democratic demands. In fact, both are closely intertwined. Boulder, Col./London, 1988, p. xvi. Emphasis in the original.

22 See J.-L. Seurin, Analyse des systèmes politiques, Bordeaux, 1991, pp. 179-195. 
It is common knowledge that the new democracies in most of the post-independence states in sub-Saharan Africa wete intolerant of the opposition, disrespectul of fundamental freedoms and thetefore took political actions which contradicted the very premises on which independence was granted to particularly the anglophone and the francophone states in the 1960s. Thus, it has been estimated that by "the early 1970s virtually all of the independent regimes in sub-Saharan Africa were either military or one-party".23 How does one account for what Jean-François Médard has qualified as the eclipse of democracy at the very moment of its triumph (at independence) in Africa?24

\section{The Domestic Setting}

\section{a) Historical Fatalism}

Some of the existing explanations for the absence of democracy in sub-Saharan Africa are fatalistic in the sense that there is a certain ring of the inevitability of dictatorship about them and to that extent they are rationalizations. To begin with, the academic argument that pleads the necessity of national unity and the exigencies of economic development as advanced by the independence leaders themselves is, at best, a rationalization and not an explanation for the collapse of democracy. To Mugyenyi, for example, democracy thrives in its minimalist form in the various forms of government prevalent in the Third World as a result of its adaptability to changing environments. 25 Like the thesis of African socialism, that of democratic flexibility has proved to be an apologia for all kinds of state dirigism whose consequence has been the gross misrule that has afflicted most sub-Saharan African states.

It was indeed the absence of democracy or its failure in most of these states and not its presence which influenced some analysts to recommend developmental dictatorship in the past as the way forward for Africa. 26 If democracy was present in all African states even in its "minimalist" form, how then does one account for the intermittent and, in some cases, persistent struggles since decolonization within some sub-Saharan African states - the "second independence" movements - whose objective has been to force the revocation of

23 L. Diamond et al., Democracy in Developing Countries: Af rica, p. 1.

24 J.-F.Médard, Autoritarisme et démocratie en Afrique noire, Politique Africaine, No. 43, October 1991, p. 102.

25 M. Mugyenyi, Development First, Democracy Second: A Comment on Minimalist Democracy, in: W.O. Oyugi et al. (eds.), Democr atic Theory and Practice in Africa, Portsmouth/London, 1988, p. 185. This thesis was criticized in the very next chapter chapter by $M$. Chege, The African Economic Crisis and the Fate of Democracy in sub-Saharan Africa, esp. pp. 199-201.

26 See A.G. Gregor, Italian Fascism and Developmental Dictatorship, Princeton, N.J., 1979, pp. 327. 333. 
the imposition of de facto and de jure one-party states and military dictatorships, in a word, the restoration of democracy?27

From a purely historical perspective, Michael Crowder would consider the quick collapse of democracy after independence in particularly the anglophone and francophone states The Gambia, Botswana and possibly Senegal being exceptions - as a matter of course. Two major reasons lay behind this inevitability. First, the idea of democracy was, to him, uniquely the dream of most of the nationalist leaders whose real conception of the term was as an instrument for the realization of their own personal political ambitions. Second, as a successor to the colonial state the post-independence African state was a model of the former by encompassing all its anti-democratic attributes: free use of violence, legitimacy based on force, denial of basic freedoms, electoral manipulations, economic exploitation and neglect. 28

In their collective volume on democracy in Africa, L. Diamond, J. Linz and S. Lipset upheld M. Crowder's submissions by identifying the causes of the failure of democracy in post-independence African states as the "immense challenge with which they were immediately confronted" as well as "historical and structural handicaps" all of which reflected the fundamental weakness of the state.29 More importantly, the origin of this variety of handicaps which stretched from ethnicity through comuption, economic dependence and inefficient political institutions to incompetent political leadership, was located in colonial conquest and rule. 30

That this was indeed so was quite obvious since by definition colonialism was both nondemocratic and anti-democratic although its harshness differed from one colonial territory to the other. The shortcomings of colonialism were the very reasons which triggered the independence struggles in the first place. Certainly, the weak foundation which this laid for independence especially in Zaire was responsible for the quick political reversal which engulfed many of these states shortly afterwards. Hence, the salient lesson to be drawn from an examination of this concatenation of factors is that it is not enough to set up democratic institutions for democracy to prevail. Nationalism has always been a poor substitute for individualism on which premise the liberal variant of the democratic theory is erected. To harp ceaselessly on the perversities of colonialism unwittingly justifies the arguments of those in authority whose set objective has always been to expand and to

27 On these struggles see PA. Nyong'o (ed.), Popular Struggles for Democracy in Africa, London, 1987.

28 M. Crowder, Whose Dream was it Anyway? Twenty-Five Years of African Independence, African Affaris, vol. 86 (342), January 1987, pp. 11-19.

29 L. Diamond et al. (eds.), Democracy in Developing Countries: Africa, p. 5.

30 Ibid., pp. 6-24. 
reinforce their personal grip on power. Recognition of exceptions to democratic failure among erstwhile colonies suggests that other explanations should be sought.

Above all, the foregoing factors do not constitute an integral explanation. For this we turn to a consideration of neo-patrimonialism whose depiction of the state shows a deliberate blurring of the analytic distinction between the public and the private realms by the political actors.

\section{b) The Sociological: the Neo-patrimonial State}

How does the concept of neo-patrimonialism account for the absence of democracy in the sub-Saharan francophone states? Neo-patromonialism is a variant of Max Weber's patrimonialism, itself a sub-type of his ideal traditional domination. The leading French Africanist in the use of patrimonialism to interpret political processes in sub-Saharan Africa, Jean-François Médard, appears to share Zaki Ergas' contention that "in virtually all African states, at this particular stage of their historical development, state-society relations are primarily defined by patrimonialism".31 As a variant of the latter, neo-patrimonialism describes a hybrid situation within which the parrimonial logic combines and mixes with other modern logics. 32 Médard identifies two fundamental characteristics with the concept. The first is the deliberate blurring of the analytic distinction between the public and the private spheres in the administration of the state including that between public and private norms. This situation culminates in the personalization of political power by office holders and in the primitive accumulation of political, economic and symbolic resources. The second is the weak autonomy of the two fields. 33 This double telescoping as it wete has grave consequences for the administration of the state and, furthermore, for civil society as well.

According to this theory, access to the state becomes a highly prized goal since its conquest permits its patrimonialization or privatization. The wielders of political power, the African leaders, conceive of politics as a means to wealth and they have to redistribute the resources in order to reinforce their hold on power thus enhancing further primitive accumulation. In the light of this, holders of public positions at diverse levels of govemment consider these as points for the exaction of prebendes. Under such circumstances, the democratic space is severely constricted as the principle of financial and political accountability falls into

31 Z. Ergas, Introduction, in: Z. Ergas (ed.), The African State in Transition, London, 1987, p. 2. Revolutionary Ethiopia was the only country exonerated from this practice. J.-F. Médard quotes Ergas approvingly. See his "L'Etat néopatrimonial", in: J.-F. Médard (ed.), Etats d'Afrique: Formations, mécanismes et crise, Paris, 1991, p. 323.

32 J.F. Médard, Etats d'Afrique, p. 334.

33 Ibid., pp. 336, 342. 
abeyance. Both economics and politics do not operate according to the logic of free choice. 34 The neo-patrimonial state is both arbitrary and authoritarian and is of ten characterized by violence whose pervasiveness within the political process has led Claude Ake to qualify political competition in Africa as warfare. 35

To be sure, the level of patrimonialism differs from one state to the other and this is also a function of the amount of resources including those from the "aid industry" 36 available to the political leaders for pillage and distribution. Most recent studies on the French-speaking states point to an abundant evidence of patrimonialism. Yves-André Fauré, for example, takes exception to the economistic interpretation of the Ivorian conjuncture to the utter neglect of its socio-political (patrimonial) underpinnings. 37 Studies on Cameroon (J.-F. Bayart), Senegal (C. Coulon and D.B. Cruese O'Brien) and Burkina Faso (R. Otayek) point to the presence of this phenomenon as the privileged modality of political regulation and control.38 The zenith of neo-patrimonialism seems to have been attained in Zaire which regime Thomas Callaghy describes as a presidential monarchy. 39 The point of neo-patrimonialism is that it represents a catastrophic management for the economies of the states in question. This consideration would lead J-F MEdard to submit that the "crisis of patrimonialism and development are tied together. the crisis of patrimonialism contributes to that of development and the crisis of development ruins the foundation of the neo-patrimonial state". 40

The whole neo-patrimonial framework a ppears as a vicious circle. The privatized state which is a rentier state seeks to control the major economic activities in the country which it manages politically and, therefore, inefficiently. Economic crisis is automatically transformed into a political crisis and vice versa. The upsurge in protests for democratization

34 Ibid., p. 342.

35 C. Ake, The Case for Democracy, in: The Carer Center of Emory University, African Govemance in the 1990x, Working Papers from the second annual seminar of the African Govemance Program, March 23-25, 1990, p. 2.

36 The expression belongs to Z. Ergas, The African State in Transition, p. 10. Acconding to Ergas, aid is the fastest growing industry in the world today.

37 Y.-A. Fauré, Côte d'Ivoire: analysing the Crisis, in: D.B. Cruise O'Brien / J. Dunn / R. Rathbone (eds.), Contemporary West African States, Cambridge, 1989, pp. 67-70; see also Y.-A. Fouré / J.F. Médard (eds.), Etat et Bourgeoisie en Côte d'Ivoire, Paris, 1982, chapters $1 \& 2$.

38 R. Otayek, Burkina Faso: Between Feeble State and Total State, the Swing Continues, in: D.B. Cruise $O^{\prime} B r i e n$ et al. (eds.), Contemporary West African States, pp. 15-16; J.-F. Bayart, Cameroon, in: ibid., pp. 44-45; C. Coulon / D.B. Cruise O'Brien, Senegal, in: ibid., p. 151.

39 T.M. Callaghy, The State-Society Struggle: Zai re in Comparative Perspective, New York, 1984. See also J.-C.Williame, L'autonomie d'une monarchie, Politique Africaine, No. 41, Manch 1991, pp. 10-21.

40 J.-F. Médard, L'Etat néo-patrimonial, p. 351. 
finds its logic in the perverse workings of the neo-patrimonial state especially for most members of civil society who bear the brunt of this practice.

Doubtless, the arguments of the neo-patrimonialists are attractive and cannot therefore be dismissed lightly in the search for the failure of democracy in the sub-Saharan African states. Certainly, the explanation which this theory offers appears more cohesive and coherent than the preceding one yet it has some limitations. First, it is ahistorical in its treatment of the trajectory of this democratic collapse. Second, it falsely assumes that the African leaders and, indeed, the African states act independently of the intervening variables in the international environment. While these leaders bear the ultimate responsibility for their domestic political and economic policies, it is widely accepted that many of them pander to and are propped by external interests. Finally, the existence of varying shades of neo-patrimonial practices in some of the matured democracies raises the question of its critical tresh-hold for the demise of demoaracy. Bearing these comments in mind, we tum to an examination of the significance of the extemal setting for the upsurge in democratization in the states under consideration.

\section{The External Setting}

The mechanisms of international exchanges are generally unf avourable to the sub-Saharan African states. It is indisputable that the worsening terms of trade between the mostly primary export products from these states and their manuf actured imports contributes to the crisis situation. So also does their indeptedness to both the London and Paris clubs. However, the fact that the neo-patrimonial state compounds this situation is partly an explanation for the intervention of the International Monetary Fund (IMF) and the World Bank through the imposition of the structural adjustment programme (SAP) on the SubSaharan African states. The implementation of the conditionalities of the SAP is the only basis on which fresh credits can be accorded and old debts rescheduled.

To the economic conditionalities of privatization of public enterprises, marketization of the economy, prudent financial management and rationalization in the public services, have now been added demands for political liberalization as evidenced by the forthright 1989 World Bank report, "Sub-Saharan Africa: From Crisis to Sustainable Growth" that puts the responsibility for the economic malaise in the African states on the crisis of govemance. 41 In principle then, the objective of the SAP is to bring back rationality into both the management of the state and of the economy. In other words, to de-patrimonialize the state

41 World Bank, Sub-Saharan Africa: From Crisis to Sustainable Growth. A Long Term Perspective Study, Washington D.C., 1989, p. 60. 
thus permitting a restoration of the analytic distinction between the public and the private spheres.

In practice, the implementation of the SAP has led to dramatic situations especially eithin the ranks of the disadvantaged groups in society. The overall thrust of the IMF and the World Bank package has accounted for the democratic aspirations in the French-speaing states and, indeed, elsewhere on the continent. The question of the SAP will be taken up much later.

Beyond the SAP, other pronouncements by external actors and, in fact, the fundamental restructuring of the intemational political environment have all contributed to the intensification of the quest for democracy within the francophone states. The major Westem industrial nations who are closely associated with economic and political choices in these states - France, the United States and Belgium, but also Britain - have made public statements in favour of political liberalization and, in fact, consider this shift as a precondition for future bilateral assistance to the countries concemed. The address given by the French President, François Mitterand, at the 1990 armual Franco-African summit at La Baule was outstanding in this respect. Like the 1989 World Bank report already referred to, the correct interpretation to be given to these various pronouncements is as a manifest support to those pressing for democratization and as both a carrot and stick to the states reacting one was or the other to such demands.

It is indeed very doubtful whether the political leaders in the French-speaking states and in such other countries as Zambia and Kenya would have accepted any form of democratization without the overt and covert pressures brought to bear on them at once by the Westem industrial nations and the IMF and the World Bank.

It is only the foregoing which can explain satisfactorily the sudden volte-face of such leaders as Felix Houphouët-Boigny (Côte d'Ivoire), Paul Biya (Cameroon), Mobutu Sese Seko (Zaire) and Gnassigbe Eyadema (Togo) whose initial rejection of multipartyism and of any form of political opering was as vehement as the waves of mass protests that assailed their administrations. President Eyadema in particular would go as far as to claim that the Togolese people did not want multipartyism and, therefore, he was not prepared to impose one on them!

Beyond this, the democratization protests in these states were propelled further by the democratic 'revolutions' in Eastem Europe and in the former Soviet Union which ended the hegemony of the communist party and somewhat, by the unfulding events in South Africa in so far as these held prospects for a democratic solution to apartheid. 
In the final analysis then, one could submit that the upsurge in democratic demands in these francophone states was due to factors within their domestic and extemal settings. The neopatrimonial nature of the state as this was sustained by extemal interests and not necessarily colonialism, as evidenced by the wast of resources and the unbridled corruption and mismanagement characteristic of the former, led inevitably to economic collapse and to the introduction of the SAP. While the extemal factors have been important, these have merely supplemented and complemented the domestic pressures, without which democratization would have remained both isolated and mostly rethorical events.

It remains to account for the level of violence which accompanied these protests and which has continued to dog the process of democratic transition in some of these states. Because the use of violence has been widespread but not exclusive to the francophone states one is inclined to argue that it was the clash of will between the political leadership intent on conserving its privileges and an opposition determined to end these which accounted for violent irruptions in Cameroon, Togo, Zaire, Côte d'Ivoire, Gabon, and Kenya for example. While the democratic outbursts are unprecedented, their significance lies in the way in which the demands have been addressed.

\section{The Mechanisms of Francophone Democratization}

The democratization pressures which erupted from the members of civil society in Benin, Niger, Mali, Zaire, Gabon, Côte d'Ivoire and Congo and the muscled response to these from the political authorities signalled the onset of a crisis of legitimacy for these regimes in the sense, on the one hand, of a dysfunction or a breakdown un the usual cluster of representations which gave support to then an, on the other hand, of a politicization of these mainly socio-economic grievances. 42

The Problem which confronted the presidents whose legitimacy had thus been challenged seemed to be how to go about this shift to political pluralism once they had been forced to accept it, without jeopardizing their grip on power. In the light of the experiences from the 'third wave democratization', Samuel Huntington has conceptualized three dominant modes of democratic transition: transformation, replacement and transplacement. According to him, transformation occurs when the elites in power take the initiative to bring about democracy while replacement takes place after the opposition has initiated the collapse or the overthrow of a non-democratic regime. Transplacement, on the other hand, is the result of a joint action, through negotiation, between the govemment and the opposition groups.

42 On the crisis of legitimacy see J. Lagroye, Sociologie Politique, Paris, 1991, pp. 401-408. 
This particular mode is marked by cycles of protests and repression ${ }^{43}$ as has been the case in all the francophone states under reference.

To argue that the transplacement mode of democratic transition has so far prevailed in the francophone states is to recognize that their political authorities were not prepared on their own initiative to democratize - as their public utterances suggested - in a mamer radically different from their pseudo-democratic overtures in the past. It is equally to recognize that their civil society lacked the decisive blow which single-handedly could bring the whole patrimonial architecture to grief. Consistent pressures from this same civil society but also from the external environment as we have argued, forced the political leadership to concede the introduction of multipartyism. With the advantage of hindsight, it was obvious that the political leadership and the elements in civil society had conflicling ideas of what democratic transition and, indeed democratization were all about. It seems to us that this was at the root of the choice of the modality for achieving this objective. Whereas some countries resorted to the use of the national conference others invoked the extant constitutional provisions for effecting this democratic transition. What were the rationale for each choice and what kind of transition has it yielded?

\section{The National Confer ence}

The decision as to whether or not to convene a national conference was cerainly influenced by a number of political calculations and by the peculiar circumstances of the countries concerned The idea of a national conference was invented by Benin whose former President, Mathieu Kerekou, saw it as a mechanism for resolving the paralysis which the opposition protests had forced on his seventeen year old military dictatorship. It was obvious that the renunciation of "Marxism-Leninism" by his regime and the legalization of multipartyism were not sufficient to stem the tide of economic cum democratization pressure from below which assailed his administration. Certainly, by the time the Beninese leader took the decision to convene a national conference in December 1989 the state's economic predicament was catastrophic as public servants went unpaid for months on end, and pressures for political liberalization were coming from both the IMF, the World Bank and France. The latter was initially pressing not for multipartyism but for a broadening of the base of Benin's single party, the Revolutionary People's Party of Benin (PRPB), but shom of its marxoid rhetoric. 44

43 S.P. Huntington, How Countries Democratize, Political Science Quarterly, vol. 106 (4), Winter 1991/92, pp. 583, 610.

44 JB.K. Monkotan, Une nouvelle voie d'accès au pluralisme politique: la conférence nationale souveraine, Afrique 2000, No. 7, November 1991, pp. 44-48; TE. Vittin, Bénin: du 'système Kérékou' au renouveau démocratique, in: J.-F. Médard (ed.), Etats d'Afrique noire, pp. 107-111. 
In the light of the foregoing, the decision to convene a national conference by Kerekou was based on a number of political calculations. First, the conference was meant to serve as a catharsis to the ebullient civil society intent on forcing his resignation thus permitting a quick retum to political décrispation and ultimately to national reconciliation by all sides in the political contest. Second, it was intended to generate ideas with which to address the thomy political and economic grievances in the society thereby permitting the country once more to move forward. Whichever was the dominant motive, it was clear that Mathieu Kerekou envisaged that the outcome of the conference would still leave him in effective control of the state. In the event, the national conference whose membership had been drawn from the voluntary associations, the human rights leagues, religious bodies, and from the newly registered political parties except the Dahomean Communist Party (PCD) but including the PRPB, proclaimed its sovereignty and went ahead to incapacitate Kerekou's presidency by circumscribing his exercise of executive powers.

At the end of its ten day deliberations, the national conference had suspended the existing constitution and the political institutions derived from it and, in their stead, set up three organs of government during the transitional period: A High Council of the Republic (HCR), a transitional Government and a President of the Republic. The HCR was made up of important personalities drawn from civil society including past Presidents of Benin and was headed by a Monsignor, Isidore de Souza. Its main task was to supervise the democratic transition process by exercising sovereign legislative functions as a successor to the national conference of the active forces of the nation. The transitional Government, under a Prime Minister (Nicéphore Soglo) elected by the conference, had responsibility for running the state as well as for organizing elections on the basis of a new constitution which the conference had adopted. Finally, the incumbent President, Mathieu Kerekou, was retained in office as the Head of State and Commander-in-Chief of the Armed Forces but his functions were merely symbolic since executive powers were vested in the transitional Government subjected to the overall control of the HCR.

The relative ease with which a complete democratic transition was achieved in Benin after the defeat of Mathieu Kerekou by Nicéphore Soglo in the run-off presidential elections in March 1991 and, indeed, the acceptance of the former to bow to this democratic verdict held up the beninese invention as a model to be copied by the other democratizers (in the Huntingtonian sense). In fact, it was not as smooth sailing as that. Initially, Kerekou had threatened to scuttle this transitional mechanism which he qualified as a civilian coup d'état but, somehow, he displayed political sagacity in his closing address to the national conference by accepting to abide by its resolutions and by formally expressing remorse to the Beninese people for mistakes made under his administration. 45 All the same, the fact

45 J.B.K. Monkotan, Une nouvelle voie d'accès au pluralisme politique, p. 50; T.E. Vittinn, Bénin: du 'système Kérékou' au renouveau dénocratique, p. 110-111. 
that Mathieu Kerekou ran for the presidency under the new democratic dispensation is prove conclusive that his speech already referred to was a mere political manoeuvre.

That the Beninese model was indeed attractive was evidenced by the clamour by the opposition groups in the french-speaking states for the convening of a national conference $\dot{a}$ la béninoise. Given this, one could argue that the decision by some of these states to convene the national conference and by some others not to convene one was based on the outcome of the Beninese democratic transition experience. In the first category of states to which Togo, Niger, Congo, Zaire, 'Gabon', Burkina Faso, and 'Mali' belong, the political elements within civil society viewed this model as a painless mechanism for resolving the problems thrown up by the democratic transition. In the second category of states, the political authorities in the Côte d'Ivoire and Cameroon in particular appeared averse to seeing the democratic transition conducted in such a manner and, a fortiori, produce the same results. First, we examine aspects of the national conferences in the former category of states.

Apart from the Gabonese and the Malian national conferences whose agenda were limited (and to which we shall return later), the democratization processes in the rest of these states have followed or are still following the Beninese model with variations, however, in the duration of their national conferences, in the kinds of problems these have run into and, in one or two cases, in the attribution of functions to the transitional organs. These conferences always proclaimed their sovereignty as the Zairian oft-posponed conference did once it reconvened in April 1992. Furthermore, they proceeded to suspend the existing constitution and political institutions and, like in Benin, establish similar organs to assure the transition.

Unlike in Benin though, the President of the HCR in Niger was named the Supreme Commander of the Amed Forces and the organ itself as the guarantor of the independence and of the territorial integrity of the nation. In Togo, this function was still left with the incumbent President, Gnassingbe Eyadema, but with the proviso that in situations of grave crisis, this responsibility would have to be exercised jointly with the President of the Presidium of the national conference, that is to say, the HCR. The Armed Forces were equally put at the disposition of the transitional Prime Minister.46 The transition process in Congo reflected similar provisions.

Another striking feature of these conferences has been the prominent role which the Catholic clergy has played in support of the democratic protests or in the democratization process itself. Some of its higher clergy (Monsignores) have been elected presidents of these national conferences and invariably of the HCR in all the states except in Mali and

46 République du Niger (CNPCN), Résultats des Travaux, Niamey, 13 mai au 17 juin, 1991, pp. 57 58. 
Niger which have predominantly muslim populations. As part of civil society, the Church has used its Episcopal conferences to issue pastoral letters, widely disseminated in the local and foreign news media, in support of democratization. Nevertheless, the kind of role which some of its higher clergy played in the past or are still playing within these societies and states has been at variance with this new advertized of ficial role as Comi Toulabor and J.-F. Bayart have stressed in recent contributions. 47

It is apropos to begin reflection on the national conference as a mechanism for democratic transition by examining its claim to sovereignty. We have argued that the democratic protests represent a crisis of legitimacy for both the self-imposed military regimes civilianized or not - and for the long-serving authoritarian one-party regimes in these francophone states. In a situation of non-rule in which many of these regimes found themselves as a result of prolonged campaigns for democratization, legitimacy could only be restored to them after an electoral legitimating process within civil society. In principle, the claim to sovereignty - defined as unlimited power exercised on behalf of the people - by the national conference derives from the wide representativeness of its social base (it embraces all the active forces of the nation) as opposed to the contested government which perpetuates itself in power by sheer repression or by electoral fraud as studies have indicated.48

This representativeness is, in fact, assumed rather than validated because delegates to the national conference were nominated by the active forces and by the government and not elected through universal suffrage. Thus, out of the 1,204 delegates to Niger's national conference, the rural population which accounts for about 90 per cent of overall national population had 64 representatives who had merely an observer status. If politics is the vocation of the elites, the correct interpretation of active forces is then that all the groups politically significant in society by virtue of their capacity to provide altemation have assumed sovereignty. This act enjoys wide support among the populace outside the patrimonial constituency of the political leadership because they are the victims of the excesses of this authority.

In practice, the proclamation of sovereignty is an astute political move designed to incapacitate the incumbent presidents in a fast-paced power struggle and not because, as Monkotan asserts, the gravity of the economic situation facing the states concerned requires an immediate solution which by-passes the usually slow process of invoking presidential

47 C.M. Toulabor, Mgr Dosseh, Archévêque de Lomé, Politique Africaine, No. 35, October 1989, pp. 68-75; J.-F. Bayart, Les Eglises chrétiannes et la politique du ventre: le partage du gâteau ecclésial, Politique Africaine, No. 35, October 1989, pp. 3-26.

48 CEAN-CERI, Aux umes l'Afriques! Elections et pouvoirs en Afrique noire, Paris, 1978; FM. Hayward (ed.), Elections in Independent Africa, Boulder, Col., 1987, pp. 271-284; N. Chazan et al., Politics and Society in Contemporary Africa, Boulder, Col., 1988, pp. 206-207. 
intervention. ${ }^{49}$ But herein lies all the problems of the national conference mechanism. It is not enough to proclaim sovereignty for every other thing to fall into place. That this mechanism worked more or less smoothly in Benin does not mean that it will be the same in the other countries thus drawing attention to the need to take the peculiarities of each country into account.

From every indication, the national conference has become an arena where all kinds of domestic and extemal interests jostle for supremacy. Given the Kerekou syndrome, most embattled presidents have sought, after agreeing to convene a national conference, to erect obstacles on its functioning as this was the case in Congo and continues to be the case in Togo and Zaire. First an attempt was made to flood the conference with hirelings as was initially the case in Zaire in order, either to disnst its proceodings or to outvote the active forces. Second, there was a consistent refusal on the part of the Togolese and the Zairian Presidents, in particular, to accept the self-proclamation of sovereignty by the conference. Despite this, Eyadema would show preferences in the appointment of a transitional prime minister by the conference. It is an open secret that external powers and some of the African states too, have offered varying levels of assistance in support of groups engaged in the democratization process.

The refusal by Eyadema to accept the sovereignty of the Togolese national conference led to the boycott of this assembly by his representatives. Moreover, the decision of this conference to ban and freeze the assets of the ruling party, the Movement of Togolese People (RPT), and the automatic elimination of Eyadema himself through article 61 of the new constitution from the presidential elections, accounted for the military interventions which almost sabotaged the whole transition process. In Congo, the military made a corporate demand for the removal of the interim prime minister, André Milongo, and insisted in any case that aspects of the decision of the Congolese sovereign national conference concerning the military (Act 282) should be reconsidered. The pretext for this action were the command and the defence ministerial appointments which Milongo's government made as part of the transitional power equation. Other military incidents erupted in Zaire and Niger where, in the latter, military officers under detention for their alleged participation in the Tuareg massacre were released by their mutinous colleagues who eventually forced the dissolution of the transitional government.

To be sure, strong-arm tactics were coded messages to the transitional organs by the embattled presidents, despite their deliberate self-effacement, that they still controlled the military. The military forces in Togo and Zaire or their vital specialized units, the presidential guards, owe personal loyalty to their presidents and the Togolese Armed Forces (FAT) 
is sui generis by the level of its domination by the members of Eyadema's ethnic group, the Kabiyé.50

Beyond the control of the Armed Forces by these presidents, it was some of the decisions taken by the national conference which were debatable. By virtue of its exercise of soveteignty, the conference appeared justified to place the overall command of these forces under the president of the HCR as in Niger or under joint command as in Togo and Congo or, in fact, wherever it pleased but this was problematical by virtue of the nature of some of these forces and in the context of the dispute over sovereignty. If this problem did not pose in Benin it was because its President, Mathieu Kerekou, had accepted the sovereignty of this conference for which he was later to be granted an immunity from prosecution for all his past misdeeds in office and also for the messy state of Benin's economy.

All the same, it would appear that there is a level beyond which the military forces cannot be used at present in order to overtum the decisions of the national conferences. If this were not so the Togolese Armed Forces would have done exactly that. Cerainly, the FAT have been used extensively by Eyadema in the on-going creeping restoration of authoritarianism in Togo. Military pressure played a significant role in the nomination of his close associates to key positions in the un-ending transitional govemment headed by Kokou Kof figoh and in the demand for the de-freezing of the assets of the former single party, the RPT. All the same, Gnassingbe Eyadema has been careful not to scuttle the democratic transition process altogether in one fell swoop. Apart from the risk of an outbreak of civil war which such a step implies in the countries concerned, both the Western industrial nations and the multilateral lending institutions - the IMF and the World Bank - which have asked for this liberalization are certain to cut off all economic assistance.

What is more, it could be doubted whether the inquisitorial rule which most national conferences assumed served the cause of democracy. Nor did the decision to prohibit any of the single parties in power. Doubtless, the revelations on gross mismanagement of public funds, on corruption and nepotism - all being aspects of neo-patrimonialism - could serve to further discredit the members of the dominant political class thereby helping to check their future political ambitions. But such considerations are beyond the pale of democratic transitions. The reading of such cahiers de doléances exacerbated passions and to that extent detracted from the democratic agenda before the national conferences. Besides, it was the cumulative consequences of the abuses of power which prompted the democratic demands in the first place.

$50 P L$. Ajavon, L'arméc dans le processus de démocratisation au Togo, Text of a seminar presented under the research group State and Society in Africa, CEAN, University of Bordeaux 1, 19 March, 1992. 
In summary, one can assert that the use of the national conference as a mechanism for democratic transition became popular among the francophone states once it proved its mettle in Benin. Its use in Togo, Congo, Niger and Zaire has encountered or is still encountering difficulties. This is not because of its inherent defects but because, on the one hand, the serving presidents have put up a more or less undisguised resistance to this mechanism and, on the other hand, the transitional Governments in particularly Niger, Togo and Zaire have encountered logistical difficulties in the implementation of the decisions of the conf erence.

It could therefore be argued that the factor of imitation more than any other acounted for tis popularity among this category of states. This means that Tessy Bakary's contention that the Côte d'Ivoire could not use this mechanism because it had no economic and political exiles to make such a demand is a mere simplistic explanation.51 The fact that the national conference has been compared, rightly or wrongly, to the French Estates General whose last appearance was on the eve of the momentous French Revolution of 1789 might well explain the reluctance of countries outside this orbit to utilize it. But this does not suggest that such demands were not formulated.

Indeed, some pressure groups in Nigeria did make such a demand. The refusal of the Nigerian government to consider the request at all was due to the fact that it already had a democratic transition programme being implemented not in response to the waves of democratic protests, but as a corollary to its assumption of power through a coup d'état. Democratic transition programmes, or what Ali Mazrui has qualified with Nigeria in mind as national political planning 52 , stretching the anticipated duration in power of any new military regime have become standard practice and, in fact, are part of a legitimating strategy in Nigera. Hence, Nigeria's democratic transition comes within Huntington's transformation mode as contestable as its democratic content is.

Be that as it may, it was the outcome of the Beninese national conference which induced Omar Bongo of Gabon to refuse to concede sovereignty to the inaugural congress which he convened in order to reconstitute the ruling single party into an enlarged political formation but was converted under opposition pressure to a national conference.53 The Gabonese example is therefore a deviant from the classical approach where national conferences proclaim their sovereignty instead of waiting for this to be granted on request. Given this

51 T.D. Bakary, La Retour au pluralisme politique en Côte d'Ivoire, Année Africaine 1990/1991, p. 174.

52 A. A. Mazrui, Planned Govemance: Economic Liberalization and Political Engineering in Africa, in: African Governance in the 1990s, pp. 23-28. Emphasis in the original.

53 C. M'ba, Gabon: La conférence nationale gabonaise: du congrès constitutif du Rassemblement social démocrate gabonais (RSDG) aux assises pour la démocratie pluraliste, Af rique 2000, No.7, November 1991, pp. 75-90. 
development, Bongo's long tenure was never seriously challenged as he insisted that the resolutions of this conference were mere propositions which he was at liberty to accept or reject. Although multiparty legislative elections were held amidst boycotts and accusations of fraud from the opposition parties, the presidential election will not come up until it is due in December 1993. The outcome of the Malian national conference was never in doubt once the new military regime under Amadou T. Touré committed itself to a democratic transition unlike that of Moussa Traoré which did not hesitate to use force to attempt to suppress the democratic demands. For Côte d'Ivoire, Burkina Faso and Cameroon, their leader's opposition to the idea of a national conference merits a separate consideration.

\section{The Constitutional Approach}

Two aspects of the proceeding at the national conference would cerainly have dissuaded President Felix Houphouët-Boigny (Côte d'Ivoire) and Paul Biya (Cameroon) from embarking on democratization through this mechanism: the self-proclamation of sovereignty with its attendant incapacitation of the president and his public trial aired often with passion. That this was especially the case for Côte d'Ivoire was ironical in a way; this country had established "days of dialogue" akin to the national conference as an informal gathering where individuals could freely express themselves before Houphouët-Boigny on the ills of the Ivorian society. The vehement opposition of these two leaders to multipartyism was well known but once intemal and external pressure made political reform inevitable, both leaders argued that there was no reason why this pluralism should not be sought on the basis of the existing constitutional provisions. Considering their governments duly elected to office and renerally respectful of the rule of law, the political leaders of these two countries interpreted democratization to mean a shift from a de facto one-party state to a de jure multipartyism. The contention that a democratic transition can be achieved without necessarily passig through the mechanism of a national conference is correct as has since been demonstrated in Cape Verde and Zambia.

Moreover, both Cameroon and Côte d'Ivoire but also Niger and Burkina Faso could claim to have deliberately embarked upon differing forms of political liberalization in the 1980 s and consequently, could not be in the same category as that of the inflexible regimes. To be sure, these countries witnessed differing levels of political opening but this was part of the continuing quest for consensual politics under a single party hegemony. To use this reasoning to resist further democratization would seem highly enoneous because these various brands of liberalization were not comprehensive enough to check the political deficiencies which culminated in the democratic protests. It has been shown sufficiently that the reforms within the Parti Démocratique de Côte d'Ivoire (PDCI) and the Union Nationale Camerounaise (UNC) which transformed itself in 1986 to become the Rassemblement Démocratique du Peuple Camerounais (RDPC) were not unqualified democratic openings since they 
merely permitted elite circulation and a reinforcement of the presidential monopoly on power. Yves Faure's submission on the introduction of semi-competitive elections within the Ivorian single-party, the PDCI, captures succintly the essence of this political liberalization:

In his battle to reimpose his leaderhsip Houphouët-Boigny has known how to meet the circumstances remarkably well. In an economic situation of austerity and rigour, he has had the tactical sense to let the electors do some of the 'dirty work', by entrusting them with the task of ousting the extravagant prebendalists of the political class whose stability was threatening the presidential monopoly. 54

It is obvious that we are far from a situation which Tessy Bakary has enthusistically described as one of incremental democratization. 55 Similarly, René Otayek has argued convincingly that the "rectification" embarked upon by Blaise Compaoré in Burkina Faso in the wake of the assassination of Thomas Sankara did not inaugurate democracy and was, in fact, itself rectified.56 All the same, it was this 'opening' initially endorsed by the opposition in this country which permitted the govemment and its supporters regrouped under the Allaince for the Respect for Democracy and the Constitution (ARDC) to reject the calls for the convening of a sovereign national conference. Given the foregoing situations in the Côte d'Ivoire and Burkina Faso and given also the illusions engendered by Paul Biya's much-vaunted overture towards political liberalism, the case for democratization cannot be over-emphasized.

In Côte d'Ivoire, the main opposition party, the Fromt Populaire Ivoirien (FPI) was not initially keen on the convening of a nations conference, unlike some other opposition formations, as a mechanism for achieving this democratization because its leader, Lawrent Gbagbo, believed that he could win an outright victory at the polls. It could be doubted whether Houphouët-Boigny would have been inclined to grant such a demand of the FPI had joined the other parties in formulating this. One can then argue that the resort to democratization through constitutionalism was the result of both the president's refusal to be dictated to and the feeble pressure from the opposition on this score. It follows then that the dismissal of the demands for a national conference in Côte d'Ivoire as emanating from "singular ignorance" on the part of the opposition is an inelegant defence of the president's choice. To argue as Bakary does that the establishment of multipartyism simply by the

54 Y.-A. Fauré, Côte d'Ivoire: analysing the Crisis, pp. 70-71; see also J.-F. Bayart, Camenoon, pp. 42-43; M.-L. Eteki-Otebala, Misère et grandeur de la Démocratie au Cameroun, Paris, 1987; C.M. Toulabor, Dix ans de 'Démocratie' au Togo: Les Faussaires de la Démocratie, Année Africaine, 1989, pp. 287-304.

55 T.D. Bakary, La Retour au pluralisme politique en Côte d'Ivoire, pp. 162-164.

56 R. Otayek, Retour au Burkina: Rectification, Politique Africaine, No. 33, March 1989, pp. 2-10; R. Otayek, Burkina Faso: La 'Rectification' Démocratique, Studia Africana, No. 3, February 1992. esp. pp. 20-22. 
reactivation of article 7 of the 1960 Ivorian constitution automatically made demands for a national conference a non-issue 57 , is to side-track the crucial point. While this argumentation is not an uncritical endorsement of the national conference, the question to which a scholarly analysis ought to respond but which Bakary does not address, is why the Ivorian leader consistently opposed multipartyism despite its entrenchment in the 1960 Ivorian constitution.

In Cameroon, a plethora of political parties which emerged from civil society following the legalization of integral multipartyism, the Union Nationale pour la Démocratie et le Progres (UNDP), the Social Democratic Front (SDF), and the long-standing Union des Populations du Cameroun (UPC), among others, regrouped under the Co-ordination of Opposition parties to demand for a national conference. More importantly, they campaigned ceaselessly through "operation dead cities" to force the hands of the Biya government over this issue. The failure of the latter to devide or to weaken the opposition parties and, indeed, to sit out the political storm with the loss of revenue which this implied, led to the convening of a Tripartite Meeting in November 1991 in an attempt to break the political deadlock.

The Tripartite Meeting was not a national conference in the usual acceptation of the term since it could not claim sovereignty, but the forty political formations out of the forty-eight registered parties, the Government and the independent personalities (traditional chiefs, Church leaders and the captains of industry) who participated sought to reach a compromise on the way forward in Cameroon's democratization process. With agreement secured on the lifting of military command over the provinces, the discontinuation of the ruinous 'dead cities' campaign, the revision of the constitution and the electoral code, amnesty fot detained democratic campaigners, a tax moratorium but not the unbanning of the Co-ordination of Opposition Parties, among others, the way was cleared for the holding of legislative, municipal and presidential elections according to the schedule announced by the government. The refusal of the SDF to endorse the Tripartite accord and to participate in the legislative elections held in March 1992 has so far not affected the substance of the democratization process.

It is instructive though that unlike the francophone states which opted for democratization through the national conference, those within the constitutional paradigm do not experience transitional govemments and consequently, do not face the period of uncertainty which has been the bane of Togo, Niger, and until recently Congo, for example. The difference in approach means that the countries in the former category have greater possibilities, despite their difficulties, of evolving a complete democratic transition than those in the latter category. That this is indeed so is seen from what has happened in Côte d'Ivoire and to a less extent in Cameroon after their mulliparty democratic elections.

57 T.D. Bakary, La Retour au pluralisme politique en Cốte d'Ivoire, p. 174. 
In Côte d'Ivoire, the FPI and the other opposition parties suffered defeat at the hands of the ruling PDCI at the three levels of these elections. Afterwards, they demanded the convening of a national conference in order to set out the parametres for a genuine democratic transition. This kind of proposition was an afterthought and, therefore, untenable because by accepting to participate in these precipitated elections, the opposition had deprived itself of the arguments for the convening of a national conference. This equally applied to a similar demand made by the Gabonese opposition parties after the hollowness of their national conference became evident.

The situation in Cameroon was somewhat more complex; the opposition was devided on the Question of a national conference. While the SDF and some other groupings who are not represented in the National Assembly called for a national conference, the UNDP which is the official opposition party in this Assembly considered this as of little immediate interest preferring instead to concentrate its efforts on fighting the municipal and the presidential elections which were initially scheduled for October 1992 and April 1993 respectively. In a deft political move, the ruling RDPC - the former single party - which failed to obtain an outright majority in the March 1992 legislative elections (88 out of 180 seats), entered into a coalition arrangement with the Movement for the Defence of the Republic (MDR), once a member of the Co-ordination of Opposition Parties. By this volteface, the MFDR automatically nullified the victory which the opposition political formations won at these legislative elections since a combination of the seats obtained by the UNDP, the MDR and the UPC would have given them an absolute majority in the National Assembly theteby permitting them to form the govemment within a precarious co-habitation arrangement.

The wranglings within the Cameroonian opposition ranks can be interpreted as an objective sought by Biya's government by encouraging the prolifer ation of independent parties; at the last account about seventy of these existed. Moreover, the appointment of Simon Achidi Achu as prime minister was designed to furcher deepen the discomfiture of this opposition. The latter hails from the same village as John Fru Ndi, the leader of the SDF, whose bastion is the anglophone North-West province lost to the RDPC by default in the last legislative election.

In opting out of the national conference mechanism, therefore, the political authorities in these three states expressed unwillingness to accept defeat in advance in a political contest which has shown transitional prime ministers to be as ambitious power seekers as anybody else.

Beyond this, how does one explain the convening of the national conference or even the adoption of the constitutional approach within the context of state-civil society relations? Of course, the arguments which have been presented so far correctly depict the adoption of 
these two mechanisms as the results of concerted pressure brought to bear on the political authorities of these states from civil society mainly and, additionally, from the IMF, the World Bank, France, Belgium and the United States. If one recalls existing interpretations of political processes in Africa, nothing suggests that civil society in these states is capable of embarking upon such a large-sale political transformation.

As a matter of fact, despite the intermittent struggles for the "second independence" in Zaire as has been analysed by Nzongola-Ntala ja 58, the more recent and dominant interpretations of state-civil society relations in this country insist on the disengagement of elements of civil society from the state and, in fact, on the incapacity of the Zairian political leadership to exercise control over the wide expanse of its national territory. 59 Here, one is back to Goran Hyden's image of the "uncaptured peasantry".

Whether one is analysing the concepts of incorporation or that of disengagement or the Hirschmanian 'exit' option from organization theory, as survivalist strategies adopted by the members of civil society vis-a-vis the state, the overwhelming impression remains that of the state dictating the tune because the foregoing concepts describe responses to its policies.

The driving force of the state, it is often asserted, is its quest for hegemony within civil society. Whereas this quest is attained at varying degrees within different countries, the prevalence of the foregoing reactions within civil society marks the limit to this hegemonic urust. Besides, Nelson Kasfir's validation, albeit in a different context, of de-participation as a deliberate strategy of excluding elements in civil society from the political process shows that contradictory processes are often at work in state-civil society relations.60

In the Marxoid61 military regimes of Mathieu Kerekou's Benin and Denis Sassou Nguesso's Congo, for example, the state would go as far as sponsoring voluntary associations and the labour as appendages of their populist state-parties. In Niger, the Second Republic would be inaugurated under the aegis of the National Movement for the Development of Society (MNSD), the former single party, whose ideology was the illdef ined development society which emphasized grass-root mobilization for development.

58 Nzongola-Ntalaja, The Second Independence Movement in Congo-Kinshasa, in: P.A. Nyong'o (ed.), Popular Struggles for Democracy in Africa, pp. 113-141.

59 J. MacGaffey, Economic Disengagement and Class Formation in Zaire, in: D. Rothchild / N. Chazan (eds.), The Precarious Balance, pp. 171-188.

60 N. Kasfir, The Shrinking Political Arena: Participation and Ethnicity in African Politics with a Case Study of Uganda, Berkeley, Ca., 1976.

61 V.T. Le Vine uses this term borrowed from N. Demerath to describe the "distorted, garbled and cliché-ridden Marxism professed by those whose claim on the doctrine has little to do with intellectual activity". See V.T. Le Vine, African Patrimonial Regimes in Comparative Perspective, The Joumal of Modem African Studies, vol. 18 (4), 1980, p. 669. 
Despite or, indeed, because of all this, democratic outbursts have been experienced in all these states with that of Niger emerging barely two months after Ali Saibou was swom in as the democratic leader of Niger's Second Republic in December 1989. The significance of the democratic outbursts would appear then to be as an articulation of political objectives from civil society different from the hegemonic ambitions of the state. An interpretation of incorporation, disengagement or exit from a purely socio-economic dimension depicts reactions to the incoherence and to the failures of the state but does not help in understanding the quest for democratization which is a complete reversal although not an elimination or a repudiation of these trends.

Similarly, if Jean-François Bayart's depiction of a docile civil society neatly dove-tailed into the state as part of the hegemonic thrust of the latter is to be accepted, then the upsurge in the democratic demands in the French-speaking states would amount almost to a revolution. Bayart's conception of the African state as social spaces in their historicity in which the hegemonic project of the state is a succession of contradictory actions taking place simultaneously - totalization/de-totalization, construction/de-construction, order/disorder etc. - admits of no clear-cut conceptual boundary between the state and civil society. 62

What is more, interactions within this state are mediated by withcraft, weird cult fetishes, dalliances and mysticism - the "boom of esoterism" - and by chains of horizontal and vertical solidarity linking the high and the low.63 If this analysis is pushed to its logical conclusion then, there should be no justification for the constitutive elements of civil society to wish to put an end to this symbiotic relationship by demanding democratization which Bayart's earlier writings suggest is a part of the process of the autonomization of this entity. 64 The underscoring of the anti-democratic and the irrational if not bizzare perversions of politics through the pervasiveness of secret cults (Franc Maçonnerie, Croix-Rose) and other such esoteric circles within the leadership hierarchy in these states by Bayart and Comi Toulabor, for example, points no doubt to the limits which such practices place on genuine democracy.65 But, at the same time, one wonders why the Western (French) members of such fratemities maintain rationality more often than not within their various democratic settings whereas their African counterparts do not and could even go as far as

62 J.F. Bayart, L'Etat en Afrique: La politique du ventre, Paris, 1989, pp. 61, 146-147, 207-208, passim. In his latest contribution, J.-F. Bayar insists that the objective of the book under reference has been to construct a paradigm for analysing politics in sub-Saharan Africa and not to offer a definitive interpretation of this; that politique $d u$ ventre is a concept and not the alpha and omega of politics in Africa. See J.F. Bayart / A. Mbembe / C. Toulabor, Le Politique par le bas en Afrique noire: contribution à une problématique de la démocratie, Paris, 1992, pp. 262-265.

63 J.F. Bayart, L'Etat en Afrique, pp. 202-204, 270-272.

64 J.-F. Bayart, CivilSociety in Africa, p. 120.

65 J.-F. Bayart, L'Etat en Afrique, pp. 202-204; C.M.Toulabor, Le Togo sous Eyadema, Paris, 1986, pp. 111-120, passim. 
participating in, or condoning the rites of human sacrifice as these have been presented in Toulabor's contribution. 66

In the final analysis, what one can say with cortainty is that the upsurge in democratic protests from civil society has broken the myth of the invincibility of the chains of mystic solidarity which supposedly bind the elites straddling this society and the state. In other words, the existence of such ties does not necessarily signify a coincidence of political interests all the time between these elites. Furthermore, the democratic outbursts have affected state-civil society relations by virtuse of the kind of response they have elicited from the political authority whether or not such countries have gone through the national conference as a mechanism for achieving democratization. It is to an examination of the import of such changes for meaningful development within the states concemed that we rum our attention.

\section{Democratization and Development}

Many contributors have pointed out the exceptionally difficult circumstances under which democratization is being pursued in Africa as a whole. Crawford Young, for example, has noted the possibility that "ethnic, religious and racial cleavages are likely to find expression in party systems, and are difficult to accommodate in hamnonious fashion". Hence, he submits that the "effort to promote democracy in the midst of accute economic distress (in Africa) is historically unprecedented".67

First, heterogeneity is not an insurmountable obstacle in the construction of democracy; it is a challenge to democracy and as such only makes this objective difficult to realize as Arend Lijphart has argued in his now classic study on plural societies. 68 Yet, this does not suggest that such difficulties may not be compounded within the context of the feeble economic structures in the French-speaking states. Second, economic crisis itself is at the centre of the whole quest for democratization because the economic collapse which Benin, Niger, Togo, Mali and Zaire have suffered as well as the acute discomfitures of Cameroon and Côte d'Ivoire, for example, is the direct consequence of the bankuptcy of neo-patrimonial and neo-colonialist management.

66 C.M. Toulabor, Bellissima Basilica Yamoussoukroensis: l'entéléchie du 'miracle ivoirien', Année Af ricaine 1990/1991, p. 270.

67 C. Young, A Look at ... Sub-Saharan Africa, in: NN. Rizopoulos (ed.), Sea-Changes: American Foreign Policy in a World Transformed, New York, 1990, p. 89.

68 A. Lijphart, Democracy in Plural Soccieties: A Comparative Exploration, New Haven, p. 1. 
In principle then the objectives of democratization in these states ought to transcend the quest for power and, indeed, the simple mechanics of effecting political succession. The crux of democracy is to let the broad framework of the political and economic development of the state be decided by the majority of the people and, in addition, to restore rationality and coherence to the administration of public affairs.

Against the background of what has been happening in the French-speaking states, Richard Sklar's advocacy of developmental democrag 69 as a pragmatic strategy for solving socioeconomic problems through a judicious and a judicious and incremental combination of democratic attributes appears now rather very modest and very cautious. It is not that his observations then were not correct especially in the light of the failures of developmental dictatorship; it is simply that the problems that he adtressed have since become desperate situations. It was this consideration which led Zaki Ergas, writing at the same period and convinced that economic development cannot really be separated from political development to call for a 'Marshall Plan' for African development provided that political conditionalities - democratization - were imposed on the recipient states. 70

This advocacy is exactly the position which the major donor nations and the multilateral lending institutions, the IMF and the World Bank, have taken in their dealings with the subSaharan African states without of course drawing up another Marshall Plan. To be sure, this policy is in line with the content of both the 1981 (Berg) and the 1989 World Bank reports whose main thrust as has been stated earlier, is the de-statization or the de-privatization of the African state in order to render it more efficient and more coherent. This policy is at the crux of the debate as to whether or not democracy should be conceived as an instrument for economic transformation. 71

This debate is an old one in the literature and we shall merely make some observations. More recent studies argue that even if there is a correlation between democracy and the level of development which indeed is a common sensical observation, there is no causality between them since there is often no interaction between the variables used in arriving at

69 RL. Sklor, Developmental Democracy, in: R.L. Sklar / C.S. Whitaker, African Politics and Problems in Development, pp. 207-308.

70 Z. Ergas, In Search of Development in Africa, in: Z. Ergas (ed.), The African State in Transition, p. 315.

71 See, for example, $P$ A. Nyong'o, Political Instability and the Prospects for Democracy in Africa, Africa Development, vol. XII (1), 1988, pp. 71-86; T. Mkandawire, Comments on Democracy and Political Instability, Africa Development, vol. XIII (3), 1988, pp. 77-82. For Nyong'o's response see, in the same volume, pp. 83-87. 
such statistical conclusions. ${ }^{72}$ Moreover, the fact that democracy thrives in such developing states as India and Botswana, for example, is a refutation of the level of development thesis. High growth rates and high levels of development have been achieved in some nondemocratic states in South-East Asia. While there are variants of democracy, this does not suggest that some economic conditions cannot indeed facilitate or, conversely, obstruct the realization and the practice of democracy. This is indeed so in spite of Vanhanen's contenion that the "prospects of democracy are not so bleak for poor countries" because it is "difficult to establish any lower limit of GNP per capita that could be regarded as a necessary condition for democratization".73

Democracy can be desired in itself because it is the only known means of checking the political nuisance 74 which neo-patrimonial abuses constitute even in democratic regimes. We argue that to desire democracy in itself does not necessarily exclude its being desired for other reasons such as, for instance, exomomic development. The one is a basic nonnegotiable rationale while the other is merely a supplementary rationale. The common denominator of both positions is the acrepencese of democracy; the disagreement is about its end. Nevertheless, there is the risk that this supplementary rationale might, under certain conditions, be a poor substitute for the basic rationale thus serving as a justification for the kind of governmental excesses with which African politics is replete. Given the neo-patrimonial antecedents of the current democratizstion processes in the French-speaking states, it is understandable that democracy should be desired in itself in order to avoid the disillusionment which will cerainly set in when its instrumentalist underpinnings fail to materialize especially in the short term. It is this caution which informs the Overseas Development Institute's contention that "... developing country experience in the 1980 s does not give firm assurance that greater democracy will result in better economic management, effective adjustment policies, or faster economic growth".75

While the foregoing is true particularly in the short term, it should not be seen to reinforce the case against de-statization which some critics of the IMF and the World Bank economic structural adjustment programmes have presented in a manner reminiscent of the kind of arguments which the neo-patrimonial leaders and monarchs in these states put forward. In

72 J.-F. Médard, Crise Africaine et Démocratisation: Les Perspectives de la Transition Démocratique en Afrique Subsaharienne, Paper presented at the Intemational Round Table on Democracy and Social Tensions in the Third World, Madras, January 27-31, 1992, p. 11.

$73 T$. Vanhanen, The Process of Democratization: A Comparative Study of 147 States 1980-88, New York, 1990, pp. 194-195.

74 J.-F. Médard, Autoritarisme et Démocratie en Afrique noire, p. 92.

75 Cited in A. Shepherd, The Economics of Democracy, Africa Repon, March/April 1992, p. 28. The main ODI publication which we are unable to lay hands on is J. Healey / M. Robinson, Democracy, Govemance and Economic Policy: Sub-Saharan Africa in Comparative Perspective, London, 1992. 
rejecting the SAP, for example, A.E. Anthony called for an adjustment programme whose objectives should, among other things, "provide the basis for delinking the African economies from the capitalist economy".76 The concept of delinkage which has emanated from dependency scholarship as a deliberate strategy in the anti-imperialist struggle derives from a structuralist and economistic interpretation of under-development to the exclusion of domestic political variables which are considered as mere reflections of the logic of global capitalist dominance. 77 In a different context and from a different analytic perspective, Fredrich Cooper would bemoan as far back as 1981 the fact that "parts of (Africa) are becoming detached from the world economy" 78 Neo-patrimonialism has as much share of the responsibility for this as the structure of the international economy. While the delinkage being advocated is said to have occurred by default 79 , the SAP itself has been conceived by some as a strategy for effecting a reconnection to the world economy.

Similarly, Björn Beckman was saying the obvious by qualifying the SAP and the 1989 World Bank report containing political conditionalities as the "foreign imposition" and in asserting that " $(t) h e$ 'conditionalities' linked to the foreign finance that goes with SAP are the hallmark of rising neo-colonialist domination".80 To take one more example. In defending the merit of the African Alternative Framework for Structural adjustment Programme (AAF-SAP), which was crafted by the United Nations Eonomic Commission for Africa (UNECA) and approved by the Heads of state of the Organization of African Unity (OAU), J.K. Thisen argued that the presumptive institutional superiority of private over public enterprises has no theoretical foundation". 81

While the World Bank's positions are not infallible, it seems to us that its identification of bad govemance as the root cause of the economic woes which have overtaken the subSaharan African states is superior to the circumstantial arguments put up by the neo-

76 AE. Anthony, African Domestic Structure, Deepening Crisis and the Current Adjustment Program, Africa Development, vol. XVI (1), 1991, p. 90.

77 See, for example, S. Amin, La Déconnexion: pour sontir du système mondial, Paris, 1985; S. Amin, La Faillite du Développonent en Afrique et dans le Tiers Monde: Une analyse politique, Paris, 1989.

78 F. Cooper, Af rica and the World Economy, The African Studies Review, vol. XXIV (2\&3), 1981, p. 49.

79 D. Bach, Afrique: La déconnexion par déf aut: Avant Propos, Numéro spécial, Etudes intemationales, vol. XXII (2), 1991, p. 245.

80 B. Beckmon, Empowerment or Repression? The World Bank and the Politics of African Adjustment, Af rica Development, vol. XVI (1), 1991, p. 54. For a more balanced analysis of the World Bank report see C.S. Whitaker, Docrines of Development and Precepts of the State: The World Bank and the Fifth Iteration of the African Case, in: RL. Sklar / C.S. Whitaker, African Politics and Problems in Development, esp. pp. 348-350.

$81 J K$. Thisen, The Design of Structural Adjustment Programs: The Af rican Altemative Framework. Africa Development, vol. XVI (1), 1991, p. 131. 
Marxists and instrumentalist critics of the SAP. Public enterprises are the very conduits through which public funds are wasted or embezzled in many sub-Saharan African states including the French-speaking states as the recent study by Contamin and Fauré on this sector in the Côte d'Ivoire reveals. 82 According to Yves Fauré:

a very important portion of the Ivory Coast's financial imbalances ... comes from the public enterpise sector ..., precisely where patrimonialism is found in an almost ideal state. One may for example point out that at the beginning of the 1980 s more than half of the public extemal debt was attributable to ten or so parapublic concems. 83

To be sure, the SAP has inflicted untold sufferings on the populace in these Frenchspeaking states and elsewhere in Africa especially in so far as the political leaders whose actions led to and aggravated these problems are not seen to be making sacrifices themselves and, in fact, have devised ways of manipulating aspects of the programme such as the comering of the privatization exercise. While the 1989 World Bank report identifies rather too closely good govemance and economic development, one should be wary of arguments which tend unwittingly to lend support to these same leaders some of whose overseas investments and bank accounts - from Felix Houphouët-Boigny, through Omar Bongo and Moussa Traoré to Mobuto Sese Seko - are believed to run into several billions of United States dollars thus making the imposition of the SAP inevitable in the first place. 84

The paradox of the SAP as a corrective measure remains that its harshness could undermine the very economic and political reforms on which it is rationalized. While the persisting socio-economic strife in Benin is further evidence that a successful democratic transition is not a panacea for economic ills, there is every reason to believe that the harshness of the SAP is likely to be more tolerated under a govemment freely chosen by the members of civil society than under one which denies them of basic freedoms. Moreover, the machinery of justice has already being invoked in Benin, Niger, Mali and Congo in quest of accountability from public officers under the contested or discredited regimes.

Having said this, it seems appropriate to determine the extent to which what has been happening in the French-speaking states so far could enhance or obstruct the democratic transition and democratization itself.

82 B.Contamin / Y.-A. Fauré, La Bataille des entreprises publiques en Côte d'Ivoire: 1'histoire d'un a justement inteme, Paris, 1990, pp. 102-104, 226.

83 Y.-A. Fauré, Côte d'Ivoire: analysing the Crisis, p. 70. See also C.M. Toulabor, Bellissima Basilica Yamoussouknoensis: l'entéléchie du 'miracle ivoirien', pp. 197-203.

84 On aspects of this see P.J.M. Tedga, Ouverture Démocratique en Afrique Noire?, Paris, 1991, pp. 221-225. 


\section{The Problems of Demacratization}

Without the resurgence of political consciousness within civil society in the Frenchspeaking states, it is doubtful whether democratization as we have defined it would ever have been embarked upon in any of them. The nature of this consciousness poses a number of problems for the democratic objective sought. First, in almost all of these countries there has been an explosion in the proliferation of political formations as a result of the authorization of unlimited multipartyism. While the political authorities in Zaire, Cameroon and Côte d'Ivoire, for example, deliberately encouraged this prolif eration in order to weaken the opposition, the phenomenon itself underlines the personal ambitions of party leaders for whom democratization has become a cheap means of acreding to power. Thus, there was much rivalry within the opposition ranks as the current squabbles in Zaire and those in Cameroon and Congo illustrate.

Cerainly, the opposition parties have sometimes come under common fronts but their sheer numbers - 257 for Zaire, 75 for Congo, 70 for Cameroon etc. - as well as the fact that many of them lack social and territorial bases, recognizable structures, and financial means make co-ordination unwieldy and to that extent impede both the democratic transition and democratization itself. That this situation has not prevented a successful transition in Benin or in Mali does not imply that the problem is unreal or that it could not pose difficulties for the consolidation of any democratic gains. Besides, while the formation of political parties on the basis of common regional, religious and sub-national interests is not, structu sensu, an anti-democratic act, the debate over such tendencies has affected the transition equation in Cameroon, Niger, Togo, Zaire and Congo.

Second, most of the more prominent figures who have championed the democratic protests in these states except in Côte d'Ivoire, are not really new political faces as such; they might have served in the embattled govemments or in the single party apparatus before breaking ranks with these leaders or might have been excluded all along from the political process as a result of the enduring rancour over political assassinations and coups d'état. It does not of course follow that those in government could not decide to press for reform after about seventeen or twenty three years of continuous personal nule as the case may be in most of these states.

But the point is important especially in the light of the manoeuvrings for power which have characterized these democratization processes in the countries already mentioned. The question then is: Are these opposition elites democrats or are they merely exploiting the political situation in order to win power? It is not easy to respond definitively to this question especially in the still hazy politics of democratic transition. But the dominant political orientation of this opposition can provide indices for some reflection on the kind of environment which it envisages to create in these states. 
Going by the proceedings in the national conferences so far, one would be tempted to conclude that there is evidence of a new determination on the part of the power elites to see accountability upheld in government. But this might be a hasty conclusion in so far as the new democratic govemments have not been tested in office. The only completed democratic transition that has been in office for up to one year is that of Benin and already, Mgr Isidore de Souza who presided this transition, is complaining that comption is more widespread now than under Kerekou's administration.85 This seems then to confirm Bayart's assertion that the democratic demand has not really repudiated the practice of politique du ventre (kleplocracy) but has merely challenged its acquisitive and redistributive modalities. 86

At another level, much has been said about the lack of a precise and a viable alternative societal project by most of this opposition.87 There can be no bigger project than that of democracy itself but the problem is that one is not sure whether this system will be institutionalized. The deliberate search by some of the members of the opposition parties in these states to hold positions in government even when they have lost elections points to the continuing prevalence of consensual politics as opposed to the strict dichotomy between the govemment and the opposition in a democratic setting. Besides this, the utility of political parties is questioned when it is recalled that Nicéphore Soglo won the presidential election in Benin without belonging as such to any political party.

All told, the manner in which the democratic transition has been pursued in some of these states diminishes the credibility of the exercise. In the Côte d'Ivoire as well as in Gabon there was incontrovertible evidence of electoral manipulation to the extent that candidates of the former single parties, the PDCI and the Parti Démocratique Gabonais (PDG) were retumed unopposed in the legislative elections on contrived grounds. Yves Fauré has contended that the PDCI would have won the elections anyway in the Côte d'Ivoire owing both to the unpreparedness of the opposition and to the efficiency of the govemment's party and administrative machine which prepared the electoral list, issued the voter's card, controlled the electronic media, organized and produced the election results including the counting of the ballots. 88

$85 \mathrm{Mgr}$ Isidore de Souza as cited in Jeune Afrique, No. 1629, 26 March-1 April 1992, p. 23. J.-P. Daloz points to persisting nepotism and patrimonialism in "democratic" Beain. See his "L'itinéraire du pionnier: sur l'évolution politique béninoise", Politique Africaine, No. 46, June 1992, pp. 132-137.

86 J.-F. Bayart, L'afropessimisme par le bas, in: J.-F.Bayart / A. Mbembe / C. Toulabor, Le Politique par le Bas en Afrique Noire, p. 260.

87 See, for example, T D. Bakary, Le Retour au Pluralisme Politique en Côte d'Ivoire, pp. 166-167.

88 Y.-A. Fawé, Sur la démocratie en Côte d'Ivoire: passé et present, Année Africaine 1990/1991, pp. 137-140. 
In the two states, the shift from a one-party state to multipartyism appears no doubt as a form of political liberalization but so long as the long-serving presidents have recained their positions, a complete democratic transition connot be said to have occurred. HouphouëtBoigny's electoral victory in October 1990 ensured that the subsequent legislative and municipal elections were mere formalities since his own position had already been secured. In Gabon, the presidential election was not on the immediate agenda since the presidency was excluded at the outset from the democratization bickerings at the non-sovereign national conference.

Given then the electoral malpractices and the deliberate strategy to weaken the opposition especially in the Côte d'Ivoire, there is a grave risk of the current political opening in this country becoming merely nominal multipertyism of the Senegalese type, where the dominance of the ruling Socialist Party (PS) appears to have been reinforced with the incorporation by "charm or threat" of the main opposition party, the Senegalese Democratic Party (PDS), into a newfangled presidential majority. The search for an enlarged political base is no doubt the deliberate policy of the Senegalese government 89 but the manif estation of this tendency in the experimental democracies of Burkina Faso and Benin, for example, makes a mockery of both the concepts of the opposition and multipartyism. In the particular case of the Côte d'Ivoire, the impression of a nominal multipartyism has since been reinforced by the trial and sentencing of the leader of the main Ivorian opposition party (FPI), Laurent Gbagbo, and other opposition personalities (since amnestied) for what amounted to a political offence. This lack of respect for the opposition as part of the democratic tradition confirms Yves Faurés assessment of the first multiparty elections in post-independence Côte d'Ivoire:

One could be tempted to deny the qualificative 'democratic' to a political regime which tolerates so many exceptions to the idea which one normally has of respect for pluralism of ideas and of political formations, of freedom and of the faimess of ballots. 90

If the Cameroonian legislative elections produced different results, these were due to the prolonged campaign by the opposition parties against Paul Biya's attempts to stifle by force at times, the nascent democratic consciousness. Besides this, Cameroon is a much more polarized society than the Côte d'Ivoire and this explains the good results which the opposition parties obtained at these elections. While it is arguable whether this would have been the case had a presidential election already confirmed Paul Biya in office as was the case in the Côte d'Ivoire and Burkina Faso, it is not certain either that the Cameroonian leader

89 C. Coulon, Senegal: The Development and Fragility of Serni-Democracy, in: L. Diamond / JJ. Linz / SM. Lipset (eds.), Politics in Developing Countries: Companing Experiences with Democracy, Boulder/London, 1990, pp. 427-428.

90 Y.-A. Fauré, Sur la démocratie en Côte d'Ivoire: passé et present, Année Africaine 1990/1991, p. 149 (our translation). 
would have won such an election with the same ease as did Houphouët-Boigny. That this would have been indeed so was confimed by Paul Biya's failure to win a convincing victory in a precipitated presidential election in October 1992. Certainly, his 39.9 percent score as against the combined score of over 59 percent for a divided opposition in a controversial one-round election was enough to give him victory. But the violence which erupted in several parts of the country in the wake of the Cameroonian Supreme Court's confirmation of this result was indicative of the depth of popular resentment over the abuses that marred this election.

In Congo, the political class remained deeply divided for a long time and the inability of Milongo's transitional govemment to organize elections led to calls for his replacement even from the newly formed political parties. The lack of preparedness or experience or both on the part of this transitional government led to the invitation of the Armed Forces to organize the democratic elections. Wheres this role contrasted with that which the Togolese Armed Forces (FAT) and the specialized units of the Zairian Armed Forces have played in support of their Commanders-in-Chief, it does not dissipate the threat which the military generally represents for democracy in sub-Saharan Africa. The examples of Nigeria and Ghana remain eloquent illustrations that elaborate democratic transitions do not foreclose a future military intervention on the political scene. All the same, it is significant that Denis Sassou Nguesso bowed out after losing to Pascal Lissouba in Congo's first multiparty presidential election in August 1992.

On balance, the difficulties which confront democratic transitions in these francophone states are not fatal to the eventual restoration of democracy. As a matter of fact, these difficulties were no altogether unexpected as Lany Diamond's quaint submission that progress towards a democratic transformation in Africa would be "gradual, messy, fifful and slow, with many imperfections along the way" 91 reminds us.

\section{Conclusion}

The upsurge in mass protests in favour of democtatization in the sub-Saharan Frenchspeaking states has, in principle, sounded the death-knell for the variety of neo-patrimonial regimes with had hitherto held sway in them. Championed by a plethora of voluntary associations, students' groups, labour unions, and political formations which were excluded naturally from influencing decision-making in the de facto and de jure one-party states, the democratic protests have served to resuscitate civil society whose emasculation had more or less been confirmed by previous interpretations of politics in these states. That the political

91 L. Diamond, Beyond Democracy: Prospects for Democracy in Africa, in: The Carter Center of Emory University, Beyond Autocracy in Africa, p. 24. 
scene has been affected one way or the other is evidenced by the various transitional processes which have been embarked upon in the countries concemed in response to internal, but also and importantly, to external pressure.

The adoption of the national conference as a mechanism for achieving this democratic transition has proved very problematical in all the countries except Benin and to some extent in Mali where good political judgment did eventually prevail. The problems which this mechanism experienced in Congo and is still experiencing in Togo, Niger and Zaire are due mainly to the intransigence of the embartled dictators but also to other geopolitical calculations between the opposition leaders in this quest for political power. It is these which explain the intrusion of the military in the four countries under reference and in the political assassination which has marked this process in Togo.

The intransigence of Gnassingbe Eyadema and Mobutu Sese Seko in particular expresses their determination to conduct the transition process in a manner similar to that which the Mauritanian and the Burkinabe leaders adoptod, that is to say, the notional democratization (pluralization) of their regimes while the location and the character of political power remain unchanged. To a large extent too, this obstinacy feeds on the partial transition which has occurred in the Côte d'Ivoire through constitutionalism and in Gabon through a nonsovereign national conference. The ease with which these various regimes that have achieved incomplete transition have got away with it reinforces the impression that appearances count more than substance in democratic transitions in sub-Saharan Africa.

It is against the foregoing background that one could qualify the democratic transitions in some of these states as a mere decompression of authoritarianism. Besides, the tribulations of the Ivorian opposition and the rearguard actions in Cameroon, Gabon, Togo and Zaire suggest that the risk of an authoritarian restoration or what Stephen Riley has dibbed a "drift back into veniality (sic) and authoritarian politics" is real.92

But given the failure of authoritarianism to promote development which itself has been at the root of the demands for democratization, it is unlikely that this risk will be concretized so long as, on the one hand, civil society remains politically conscious and, on the other hand, the multilateral lending institutions and the major Western industrial powers sustain the pressure for political liberalization. The problem becomes then how to sustain the political interest and the democratic consciousness of the elements in civil society. While a definitive pronouncement cannot be made on this issue at present, suffice it to say that the low turn out at the legislative and the presidential elections in Burkina Faso and Mali in

92 S.P. Riley, The Democratic Transition in Africa: An end to the One-Party-State?, Conflict Studies, No. 245, October 1991, p. 32. 
particular raises serious questions over the ends of democratization as this is perceived by the ordinary and mostly rural voters in the two countries. 93

To ponder over the prospects of democracy in these states can be apprehended in two senses. First, it is an interrogation over the possibility that democracy will be installed in them. Second, it is a reflection upon the durability of this form of government once it has been established. The two are closely interconnected.

In the event of a successful or partial democratic transition, various institutional forms of democratic govemance - multipartyism, competitive elections, independent press, checks and balances - are brought into being and are constitutionally guaranteed. But democracy is much more than the interplay between the institutions of government. This essay has analysed the efforts being made to achieve democracy as well as the impediments to the formalization of democratic govemance in the states under consideration. Whenever these hurdles are cleared, that is to say, a complete democratic transition is achieved in all of them, the problems posed by democratization will remain.

Democratization has been conceived here first, as a long term process involving the internalization of the democratic ethos by individuals and groups in civil society as well as by the operators of the system and, second, as a process of the institutionalization of the democratic structures. The realization of these objectives will depend to a large extent upon how three groups of players manage this principle. First, the new power inheritors have to show the capacity to abide by the rules of the game. Second, those authoritarian leaders who have converted to democracy will have to operate on a framework different from what they were used to. Third, the various structures of govemment, the groups and the individuals in civil society or straddling this entity and the state have to remain effective in order to counter the hegemonic ambitions of power.

An implicit presumption in the foregoing discussion is that democracy itself is likely to be achieved. This is not exactly so. The difficult economic circumstances under which this democratization is being pursued has been sufficiently underscored. These are not fatal to the realization of democracy but make this a rather arduous enterprise. In the midst of acute economic distress, democracy may not be exactly a panacea for these ills but it will lay the foundation for the populace to hold political leaders accountable for actions against the overall interest of the nation and to that extent, democracy will permit them to bear the burden of the economic structural adjustment programme with fortitude.

93 This aspect of the transition has been discussed in E. Le Roy, Mali: La Troisième République face à la méfiance des ruraux, Politique Africaine, No. 46, June 1992, pp. 138-142; R. Otayek, Burkina: Les Raisons d'une Victoire, manuscript, p. 2. 
All the same, the past experiences of Nigeria and Ghana with elaborate democratic restoration show that the military remains a mortal danger to democracy in sub-Saharan Africa. To be sure, the excesses of the civilian regimes play into the hands of the military but many members of the latter organization have their proper political projects and will only be glad to find a convenient pretext to put these into operation. Part of the objectives of democratization will be to socialize both the military and the heterogeneous groups in society into new role conceptions and obligations to the state and society at large.

In the final analysis, there will be need for the Westem industrial nations who were once induced by Cold War considerations to condone the worst excesses of dictatorships in the French-speaking states and elsewhere on the continent, to continue to support the current democratic project as a means of stopping the patrimonialization of the aid offered to them. The latter tendency has been largely responsible for the crisis of under-development in these states. 


\section{Democratic Transition and Democratization in Francophone Africa}

\section{By Emeka Nwokedi}

Some dominant interpretations of African politics affirm the emasculation of civil society by the authoritarian one-party state and the military dictatorships rampant on the continent. They affirm, equally, the proclivity of members of this society to seek to incorporate into or to disengage from the state as their favourite strategies for survival. The upsurge in mass protests from this same civil society in favour of political liberalization - multipartyism - in sub-Saharan Africa necessitates a re-examination of state-civil society relations. An analysis of the democratization processes in some sub-Saharan Francophone states reveals the crucial role played by civil society whether or not this transition has been achieved through the instrumentality of the national conference. While the democratic transition within this group of countries faced undisguised imponderables and, in some cases, manipulative resistance from the power incumbents, the overall evidence suggests that the foundation for a further democratization has been laid in the states which have achieved either full of partial transition. Given the economic straits in which these states find themselves, the installation of democracy will be an arduous process but democracy itself appears as the minimum condition which should complement the ongoing economic structural adjustment programmes in rebuilding their capacities and in injecting efficiency and accountability into the management of the state. 